\title{
SARS-CoV-2 Vaccination Among Incarcerated People: A Barrier to Overcome
}

\author{
Vito Fiore ${ }^{1,2 *}$, Andrea De Vito ${ }^{1}$, Giordano Madeddu ${ }^{1,2}$ and Sergio Babudieri ${ }^{1,3}$ \\ 1 Unit of Infectious Diseases, Department of Medical, Surgical and Experimental Sciences, University of Sassari, Sassari, Italy, \\ ${ }^{2}$ Italian Society of Penitentiary Healthcare, Sassari, Italy, ${ }^{3}$ SIMSPe School, Viterbo, Italy
}

Keywords: COVID-19, prison settings, vaccination, prevention and control, pandemic

\section{INTRODUCTION}

By the end of December 2019, a new severe respiratory syndrome was identified in Wuhan, China (1). In a couple of months, the SARS-CoV-2 disease (COVID-19) was declared as a public health emergency by the $\mathrm{WHO}(2)$.

COVID-19 has a broad spectrum of features, such as fever, cough, and dyspnea, while

OPEN ACCESS

Edited by:

Lara Tavoschi,

University of Pisa, Italy

Reviewed by:

Md. Shahidul Islam,

University of Dhaka, Bangladesh

Shaolei Teng,

Howard University, United States

*Correspondence:

Vito Fiore

vitofiore30010516@gmail.com

Specialty section:

This article was submitted to Infectious Diseases - Surveillance,

Prevention and Treatment,

a section of the journal

Frontiers in Public Health

Received: 03 May 2021

Accepted: 09 July 2021

Published: 12 August 2021

Citation:

Fiore V, De Vito A, Madeddu G and Babudieri S (2021) SARS-CoV-2

Vaccination Among Incarcerated People: A Barrier to Overcome.

Front. Public Health 9:704520.

doi: 10.3389/fpubh.2021.704520 less common symptoms are fatigue, headache, anosmia, ageusia, skin rash, and gastrointestinal symptoms (3-5). A higher risk of disseminated intravascular coagulation and venous thromboembolism has also been described (6). Regarding severity and mortality, different factors have been studied, such as old age (age $>65$ years), as well as people with preexisting cardiological or cerebrovascular diseases (7-9).

The global health emergency caused by SARS-CoV-2 infection appears unstoppable all over the world, showing a wide spectrum of symptoms, with millions of people being infected and with a very high and unpredictable number of deaths. The spread of the coronavirus certainly does not stop in front of the prison walls and this setting appears at high risk for SARS-CoV-2 infections, given the restricted condition and overcrowding.

Furthermore, incarcerated people are highly vulnerable to coronavirus infection due to their high rates of acute and chronic health disorders, as well as the possibility of less environmental hygiene $(10,11)$. This makes this environment one of the most important challenges for infection control. More tailored interventions are needed to avoid the spread of SARS-CoV-2 in penitentiary institutes.

\section{ITALIAN PRISON SETTINGS AND PREVENTIVE MEASURES DURING THE PANDEMIC}

In 2020, a total of 96,049 people passed through the 190 prisons in the Italian Penitentiary System, with daily attendances of about 52,000-54,000. Over the last year, the number of new incarcerations reduced by 10,921 (9.3\%) compared with 2019 , and even if it decreased from above $22 \%$ to a current $6 \%$, the problem of overcrowding of the system still remains (12).

From the start of the pandemic implementing prevention and control strategies, such as reducing prison permissions, visitors, and giving access exclusively to the essential staff, were attempted (13). Moreover, triage areas, isolation in dedicated prison arms, and collection of biological samples were set-up $(13,14)$. 
TABLE 1 | Studies on SARS-CoV-2 spread in prison settings revised in our literature search (values calculated from available data).

\begin{tabular}{|c|c|c|c|c|c|}
\hline Literature & Country & Tested population, $\boldsymbol{n}$ & SARS-CoV-2 infected, $n$ (\%) & Hospitalized, $n$ (\%) & Deaths $n(\%)$ \\
\hline Cerrato et al. (18) & Italy & 453 & 58 (12.8\%) & $5(8.6 \%)$ & $3(5.2 \%)$ \\
\hline de Matos (20) & Brazil & NA & 531 (NA) & NA & 22 (4.1\%) \\
\hline Marco et al. (22) & Spain & 148 & 33 (22.3\%) & $1(3 \%)$ & - \\
\hline Njuguna et al. (21) & U.S. & 98 & $71(72 \%)$ & NA & NA \\
\hline Saloner et al. (19) & U.S. & $1,295,285$ & 42,107 (3.3\%) & NA & $510(1.2 \%)$ \\
\hline
\end{tabular}

\section{SARS-COV-2 SPREAD IN PRISON SETTINGS}

Prevention strategies are fundamental for reducing viral spread, and only some focuses of SARS-CoV-2 have been reported in Italian prisons by literature $(11,15,16)$. However, many applied measures resulted in a paradox, reducing incarcerated rights of the people when protecting public health (16). Besides, this is not sufficient for total control and prevention. As a demonstration, a very recent focus in Rome was reported, and the only new measure considered was to evacuate the prison (17).

As per current Ministry of Justice data, SARS-CoV-2 prevalence in Italian prison settings is $0.3 \%(180 / 52,517)$ among incarcerated people and $0.4 \%(160 / 36,939)$ among the prison police. Overall, $3 \%$ is actually hospitalized (12).

There is a lack of international literature on SARS-CoV2 among incarcerated people, and with different screening approaches. Cerrato et al. reported a prevalence of SARS-CoV2 up to $12.8 \%$ in a cohort of 453 incarcerated people (18). Saloner et al. analyzed data on more than $1,000,000$ people in federal and state prisons, finding a prevalence of 3.3\% (19). de Matos reported 531 cases in Brazilian prison system, with $4.1 \%$ of deaths (20). Njuguna et al. reported results from a serial laboratory testing in Luisiana during 2020. In this case, out of 98 people tested for SARS-CoV-2, 72\% were positive (21). Marco et al. reported data on a SARS-CoV-2 outbreak in a Barcelona prison. Among 148 incarcerated people who underwent nasopharyngeal swab, 22.3\% tested positive for SARS-CoV-2 (22). The available study findings have been reported in Table 1.

Considering the available literature, the reported infection prevalence is highly variable, probably also for the different testing approaches among prison population (e.g., symptoms based or extended testing programs). Substantially, these data highlighted the need for more tailored interventions and a homogenous approach in prison settings, with better coordination from the health authorities.

\section{FACING SARS-COV-2 SPREAD IN PRISON SETTINGS: PERSPECTIVES AND CONCERNS}

When considering international reports, correctional institutes were involved in multiple SARS-CoV-2 outbreaks worldwide, with crude COVID-19 death rate higher than the outside community (19).
As well it is known, correctional settings are at higher risk for SARS-CoV-2 spread due to overcrowding, poor air exchange, high population turnover, and less healthcare provision. For this reason, experts continue to point out the need to include prisons as prioritized environments regarding SARS-CoV-2 vaccine. Despite this, incarcerated people have not been included as vaccine trial populations (23). Many trials have been conducted to evaluate the efficacy and safety of the different proposed vaccines, but none enrolled people living in correctional facilities (24).

\section{DISCUSSION}

Social problems have a high impact among incarcerated people. Disparities on ethnicity, gender, age, and class have been welldescribed in literature (25). Furthermore, a high prevalence of people who inject drugs is present in Italian penitentiary settings (12). As a consequence, reaching out to patients for the vaccine administration after coming back to freedom would certainly be more difficult than during their stay in the closed prison community. Numerous papers have been published, demonstrating how incarceration is sometimes an extraordinary occasion for infectious diseases prevention and control (26-28). Also for these reasons, the vaccination of people living in a prison could also protect the entire community. Reinhart and Chen demonstrated how almost $16 \%$ of SARS-CoV-2 infected people in Chicago were correlated with the Cook County Jail outbreak (29). An outbreak inside prisons does not concern only the incarcerated people but also all people working in prison, in courts, and their relatives. In this regard, it is necessary to remember that, after having limited or closed access to relatives of detainees, the only vehicle that SARS-CoV-2 has to enter the closed prison communities is those who work there. For this reason, vaccination campaigns should place all prison workers such as policemen, administrators, educators, sociologists, and health professionals in the first place to prevent the virus from attacking the prison population. Incarcerated people should be vaccinated immediately after for the numerous reasons already outlined. If the vaccination campaign would be implemented, it could be considered to perform serology and nasopharyngeal swab only to new entries, both incarcerated people and operators. In this way, the virus would be locked out from the closed community. This kind of approach could be applied in all penitentiary settings, particularly thanks to lower costs of rapid testing. 


\section{CONCLUSIONS}

Correctional facilities have all the conditions to be considered as an integral part of the global community and to not be considered as separate entities.

In such a restricted environment, not having the free choice of being able to join a vaccination program does not result in protection, but into a further, not imposed by the Judge, restriction on individual freedom, together with the real risk of a coronavirus infection without having the possibility of selfdetermination in the choice of treatments as one has in freedom.

\section{REFERENCES}

1. Commission WMH. Report of Clustering Pneumonia of Unknown Etiology in Wuhan City. (2019). Available online at: https://wjw.wuhan.gov.cn/front/web/ showDetail/2019123108989 (accessed March 8, 2021).

2. WHO. Coronavirus Disease (COVID-19), Weekly Operational Update on COVID-19. (2020). Available online at: https://www.who.int/publications/ $\mathrm{m} /$ item/weekly-operational-update-\$-\$30-october-2020 (accessed March 8, 2021).

3. Vaira LA, Hopkins C, Salzano G, Petrocelli M, Melis A, Cucurullo $\mathrm{M}$, et al. Olfactory and gustatory function impairment in COVID-19 patients: Italian objective multicenter-study Head Neck. (2020) 42:15609. doi: 10.1002/hed.26269

4. De Vito A, Geremia N, Fiore V, Princic E, Babudieri S, Madeddu G. Clinical features, laboratory findings and predictors of death in hospitalized patients with COVID-19 in Sardinia, Italy. Eur Rev Med Pharmacol Sci. (2020) 24:7861-8. doi: 10.26355/eurrev_202007_ 22291

5. Geremia N, De Vito A, Gunnella S, Fiore V, Princic E, Panu Napodano $\mathrm{C}$, et al. A case of vasculitis-like skin eruption associated with COVID19. Infect Dis Clin Pract. (2020) 6:e30-1. doi: 10.1097/IPC.00000000000 00952

6. Niu S, Tian S, Lou J, Kang X, Zhang L, Lian H, et al. Clinical characteristics of older patients infected with COVID-19: a descriptive study. Arch Gerontol Geriatr. (2020) 89:104058. doi: 10.1016/j.archger.2020.1 04058

7. Liu K, Chen Y, Lin R, Han K. Clinical features of COVID-19 in elderly patients: A comparison with young and middle-aged patients. J Infect. (2020) 80:e14-8. doi: 10.1016/j.jinf.2020.03.005

8. Du RH, Liang LR, Yang CQ, Wang W, Cao TZ, Li M, et al. Predictors of mortality for patients with COVID-19 pneumonia caused by SARSCoV- 2: a prospective cohort study. Eur Respir J. (2020) 55:2000524. doi: 10.1183/13993003.00524-2020

9. De Vito A, Fiore V, Princic E, Geremia N, Panu Napodano CM, Muredda AA, et al. Predictors of infection, symptoms development, and mortality in people with SARS-CoV-2 living in retirement nursing homes. PLoS ONE. (2021) 16:e0248009. doi: 10.1371/journal.pone.0248009

10. Azienda Regionale Sanità Toscana. La Salute dei Detenuti in Italia: $i$ Risultati di Uno Studio Multicentrico. Florence: ARS Toscana (2015). Available online at: https://www.ars.toscana.it/files/pubblicazioni/Volumi/ 2015/carcere_2015_definitivo.pdf (accessed March 22, 2021).

11. Tavoschi L, Monarca R, Giuliani R, Saponaro A, Petrella S, Ranieri R, et al. Prevention and control of COVID-19 in Italian prisons: stringent measures and unintended consequences. Front Public Health. (2020) 8: 559135. doi: 10.3389/fpubh.2020.559135

12. Italian Ministry of Justice. Statistics (2021). Available online at: https://www. giustizia.it/giustizia/it/mg_1_14.page (accessed March 11, 2021).

13. Ministero della Giustizia. Decreti, Circolari, Direttive, Provvedimenti e Note. (2021). Available online at: https://www.giustizia.it/giustizia/it/mg_1_8.page? all=true\&viewcat=csdc_tipologia3\&selectedNode=0_62 (accessed March 11, 2021).
Prioritization for SARS-CoV-2 vaccine distribution among incarcerated people is still a challenge. Actually, the efficacy and safety of all the vaccines have been well-demonstrated. However, distribution in correctional settings remains a barrier that has to be overcome as soon as possible.

\section{AUTHOR CONTRIBUTIONS}

All authors contributed to manuscript conceiving, drafting, and approved the final version.

14. Mancinelli R, D’Ancona FP, Libianchi S, Mustazzolu A, Tavoschi L, Pantosti A. Indicazioni per la prevenzione e il controllo di COVID-19 negli istituti penitenziari e in altre strutture con limitazione delle libertá personali per adulti e minori. Not Ist Super Sanità. (2020) 33:23-7.

15. Cingolani M, Caraceni L, Cannovo N, Fedeli P. The COVID-19 epidemic and the prison system in Italy. J Correct Health Care. (2020) 6:1078345820929733. doi: 10.1177/1078345820929733

16. World Health Organization. Experience of Health Professionals, Police Staff and Prisoners in Italy Informs WHO COVID-19 Guidelines for Prisons. (2020). Available online at: https:/www.euro.who.int/en/countries/italy/news/news/ 2020/5/experience- of-health-professionals,-police-staff-and-prisoners-initaly-informs-who-covid-19-guidelines-for-prisons (accessed March 11, 2021).

17. Romatoday Il focolatio a Rebibbia non si arresta: il carcere va sfollato. (2021). Available online at: https://www.romatoday.it/cronaca/il-focolaio-arebibbia-non-si-arresta-il-carcere-va-sfollato.html (accessed April 18, 2021).

18. Cerrato F, Esposito M, Drusiani A, Moi I, Franciosi E, Assueri N, et al. Locking out the virus: management of a SARS-CoV-2 outbreak in an Italian prison. Int J Prison Health. (2021). doi: 10.1108/IJPH-12-202 0-0100. [Epub ahead of print].

19. Saloner B, Parish K, Ward JA, DiLaura G, Dolovich S. COVID-19 cases and deaths in federal and state prisons. JAMA. (2020) 324:6023. doi: 10.1001/jama.2020.12528

20. de Matos MA. New Coronavirus (SARS-CoV-2): advances to flatten the curve the prison population. Rev Soc Bras Med Trop. (2020) 53:e20200219. doi: 10.1590/0037-8682-0219-2020

21. Njuguna H, Wallace M, Simonson S, Tobolowsky AF, James AE, Bordelon $\mathrm{K}$, et al. Serial laboratory testing for SARS-CoV-2 infection among incarcerated and detained persons in a correctional and detention facility Louisiana, April-May 2020. MMWR Morb Mortal Wkly Rep. (2020) 69:83640. doi: 10.15585/mmwr.mm6926e2

22. Marco A, Gallego C, Pérez-Cáceres V, Guerrero RA, Sánchez-Roig M, Sala-Farré RM, et al. Public health response to an outbreak of SARS-CoV2 infection in a Barcelona prison. Epidemiol Infect. (2021) 149:e91. doi: 10.1017/S0950268821000789

23. Strassle C, Jardas E, Ochoa J, Berkman BE, Danis M, Rid A, et al. Covid-19 vaccine trials and incarcerated people - the ethics of inclusion. $N$ Engl J Med. (2020) 383:1897-9. doi: 10.1056/NEJMp2025955

24. Wang EA, Zenilman J, Brinkley-Rubinstein L. Ethical considerations for COVID-19 vaccine trials in correctional facilities. JAMA. (2020) 324:10312. doi: 10.1001/jama.2020.15589

25. Western B, Pettit B. Incarceration and social inequality. Daedalus. (2010) 139:8-19. doi: 10.1162/DAED_a_00019

26. Pontali E, Fiore V, Ialungo AM, Ranieri R, Mollaretti O, Barbarini G, et al. Treatment with direct-acting antivirals in a multicenter cohort of HCV-infected inmates in Italy. Int J Drug Policy. (2018) 59:503. doi: 10.1016/j.drugpo.2018.06.017

27. Fiore V, Ranieri R, Dell'Isola S, Pontali E, Barbarini G, Prestileo T, et al. Feasibility and efficacy of 8 week Glecaprevir/Pibrentasvir to treat incarcerated viraemic HCV patients: a case-control study. Liver Int. (2021) 41:271-5. doi: 10.1111/liv.14745 
28. Fiore V, De Matteis G, Ranieri R, Saderi L, Pontali E, Muredda $\mathrm{A}$, et al. HCV testing and treatment initiation in an Italian prison setting: a step-by-step model to micro-eliminate hepatitis C. Int J Drug Policy. (2021) 90:103055. doi: 10.1016/j.drugpo.2020.1 03055

29. Reinhart E, Chen DL. Incarceration and its disseminations: COVID-19 pandemic lessons from Chicago's Cook County Jail. Health Aff. (2020) 39:1412-8. doi: 10.1377/hlthaff.2020. 00652

Conflict of Interest: The authors declare that the research was conducted in the absence of any commercial or financial relationships that could be construed as a potential conflict of interest.
Publisher's Note: All claims expressed in this article are solely those of the authors and do not necessarily represent those of their affiliated organizations, or those of the publisher, the editors and the reviewers. Any product that may be evaluated in this article, or claim that may be made by its manufacturer, is not guaranteed or endorsed by the publisher.

Copyright (c) 2021 Fiore, De Vito, Madeddu and Babudieri. This is an open-access article distributed under the terms of the Creative Commons Attribution License (CC $B Y)$. The use, distribution or reproduction in other forums is permitted, provided the original author(s) and the copyright owner(s) are credited and that the original publication in this journal is cited, in accordance with accepted academic practice. No use, distribution or reproduction is permitted which does not comply with these terms. 